\title{
A SEM, EDS and vibrational spectroscopic study of the clay mineral fraipontite
}

\author{
Frederick L. Theiss ${ }^{a}$, Andrés López ${ }^{a}$, Ricardo Scholz ${ }^{\mathrm{b}}$, Ray L. Frost ${ }^{\mathrm{a}, *}$

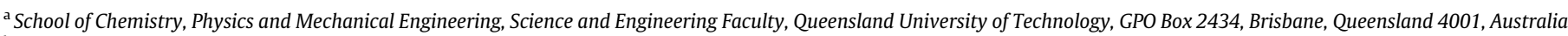 \\ ${ }^{\mathrm{b}}$ Geology Department, School of Mines, Federal University of Ouro Preto, Campus Morro do Cruzeiro, Ouro Preto, MG 35400-00, Brazil
}

\section{H I G H L I G H T S}

- Fraipontite is a member of the $1: 1$ clay minerals of the kaoliniteserpentine group.

- Chemical analysis provides a formula of $(\mathrm{Cu}, \mathrm{Zn}, \mathrm{Al})_{3}(\mathrm{Si}, \mathrm{Al})_{2} \mathrm{O}_{5}(\mathrm{OH})_{4}$.

- The mineral structure was assessed using vibrational spectroscopy.

\section{A R T I C L E I N F O}

\section{Article history:}

Received 22 October 2014

Received in revised form 26 February 2015

Accepted 20 March 2015

Available online 26 March 2015

\section{Keywords:}

Fraipontite

Phyllosilicate

Kaolinite

Raman spectroscopy

Infrared spectroscopy

\section{G R A P H I C A L A B S T R A C T}

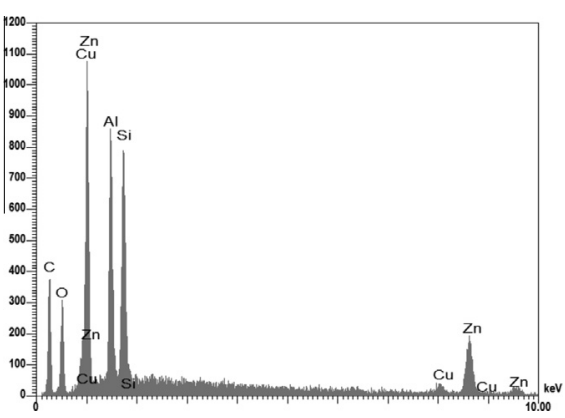

\begin{abstract}
A B S T R A C T
The mineral fraipontite has been studied by using a combination of scanning electron microscopy with energy dispersive analysis and vibrational spectroscopy (infrared and Raman). Fraipontite is a member of the 1:1 clay minerals of the kaolinite-serpentine group. The mineral contains $\mathrm{Zn}$ and $\mathrm{Cu}$ and is of formula $(\mathrm{Cu}, \mathrm{Zn}, \mathrm{Al})_{3}(\mathrm{Si}, \mathrm{Al})_{2} \mathrm{O}_{5}(\mathrm{OH})_{4}$. Qualitative chemical analysis of fraipontite shows an aluminium silicate mineral with amounts of $\mathrm{Cu}$ and $\mathrm{Zn}$. This kaolinite type mineral has been characterised by Raman and infrared spectroscopy; in this way aspects about the molecular structure of fraipontite clay are elucidated.
\end{abstract}

(C) 2015 Elsevier B.V. All rights reserved.

\section{Introduction}

Clays are an important group of minerals which are found in soils, sediments and are also the result of some hydrothermal alteration. Clay minerals form a part of the phyllosilicates or layered silicates, which are characterised by a sheet-like structure [1-3]. Both the order and composition of these sheets contributes to the properties of the clay mineral. A large and important group of clay minerals is the kaolinite-serpentine which consists of

\footnotetext{
* Corresponding author. Tel.: +61 73138 2407; fax: +61 731381804 .

E-mail address: r.frost@qut.edu.au (R.L. Frost).
}

phyllosilicate minerals including: kaolinite, antigorite, chrysotile and dickite [4]. Other minerals in this group that can be part of hydrothermal paragenesis associated to ore deposits are manandonite, pecoraite and fraipontite [5,6], which is the focus of our current investigation.

Fraipontite is a $1: 1$ clay mineral with the formula $(\mathrm{Cu}, \mathrm{Zn}, \mathrm{Al})_{3}$ $(\mathrm{Si}, \mathrm{Al})_{2} \mathrm{O}_{5}(\mathrm{OH})_{4}$. As demonstrated by the above formula, the mineral contains Zn. Takahashi et al. [17] showed that the Al was able to occupy both the octahedral and tetrahedral positions in fraipontite. Fraipontite has been described from Turkmenistan, where it was formed during thermal activity [7,8]. Perez et al. [9] described intermediate solid solutions between berthierine and fraipontite in 
Be and $\mathrm{Zn}$ mineralisation in the biotite granite and syenite Taghouaji complex (Air Mountains, Niger), while Parcalabescu et al. $[10,11]$ described fraipontite from the northern Bals batholith in Romania. Several other known occurrences have been described in [12-15]. Synthetic analogues of fraipontite have also been produced and characterised [16-18], however, such synthetic compounds are may not necessarily exhibit the same structure and properties as samples of the natural mineral.

In this article, we expand our knowledge of the 1:1 kaolinite type minerals through the study of a specific member of this group, the mineral fraipontite. The vibrational spectra (infrared and Raman) of fraipontite are investigated and related to the structure of the mineral. Qualitative chemical analysis utilising scanning electron microscopy with energy-dispersive X-ray spectroscopy has also been obtained.

\section{Experimental}

Samples description and preparation

The fraipontite sample studied in this work forms part of the collection of the Geology Department of the Federal University of Ouro Preto, Minas Gerais, Brazil, with sample code SAC-091. The sample is from the Blue Bell mine, USA.

The sample was gently crushed and the associated minerals were removed under a stereomicroscope Leica MZ4. The

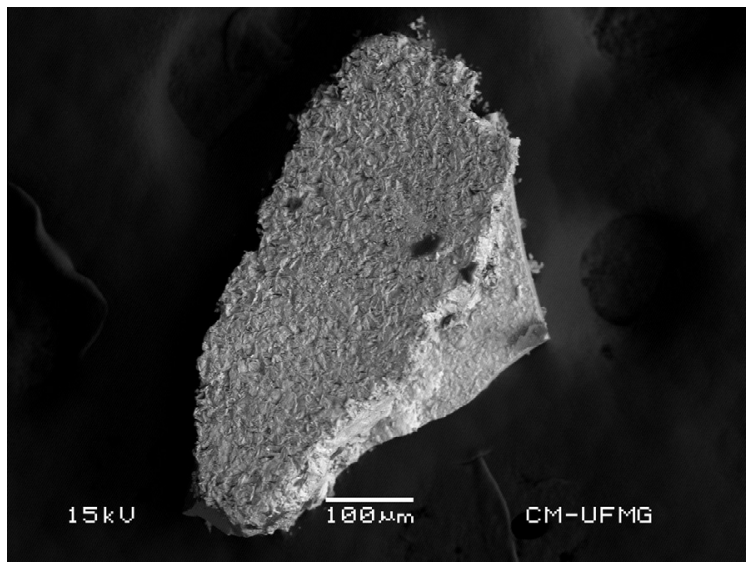

Fig. 1. Backscattered electron image (BSI) of a fraipontite single crystal up to $1.0 \mathrm{~mm}$ in length.

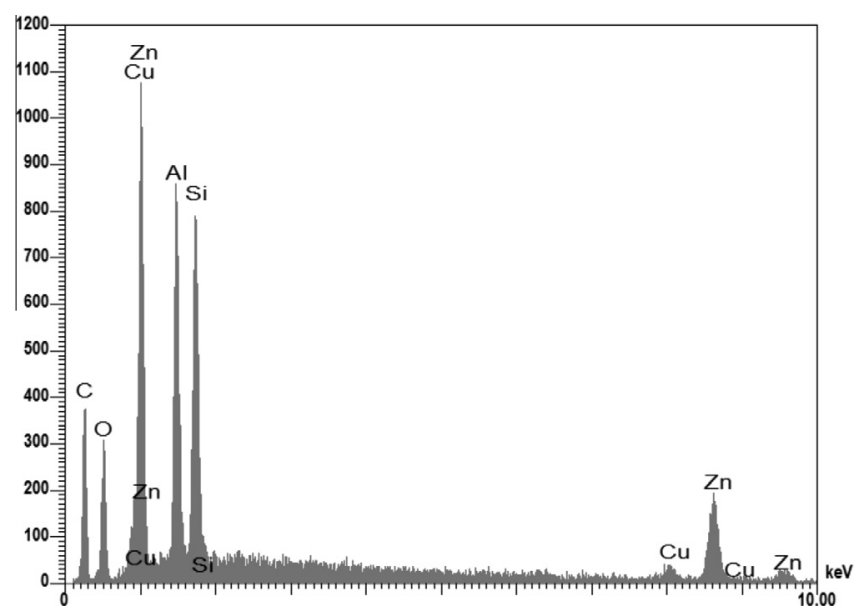

Fig. 2. EDS analysis of fraipontite. fraipontite studied in this work occurs in association with an unidentified clay mineral. Scanning electron microscopy (SEM) in the EDS mode was applied to support the mineral characterisation.

\section{Scanning electron microscopy (SEM)}

Experiments and analyses involving electron microscopy were performed in the Center of Microscopy of the Universidade Federal de Minas Gerais, Belo Horizonte, Minas Gerais, Brazil (http://www.microscopia.ufmg.br).

Fraipontite crystals were coated with a $5 \mathrm{~nm}$ layer of evaporated carbon. Secondary Electron and Backscattering Electron images were obtained using a JEOL JSM-6360LV equipment. Qualitative and semi-quantitative chemical analyses in the EDS mode were performed with a ThermoNORAN spectrometer model Quest and was applied to support the mineral characterisation.

\section{Raman spectroscopy}

The crystals of fraipontite were placed and oriented on the stage of an Olympus BHSM microscope, equipped with $10 \times$ and $50 \times$ objectives and part of a Renishaw 1000 Raman microscope system, which also includes a monochromator, a filter system and a Charge Coupled Device (CCD). Raman spectra were excited by a HeNe laser $(633 \mathrm{~nm})$ at a nominal resolution of $2 \mathrm{~cm}^{-1}$ in the range between 100 and $4000 \mathrm{~cm}^{-1}$. Details of the experimental procedure have been published. The spatial resolution of the instrument is $1 \mu \mathrm{m}$. Thus, if crystals are less than this value, a mixture of crystals will be measured. However, the crystals of fraipontite used in this experiment were $>1.1 \mu \mathrm{m}$.
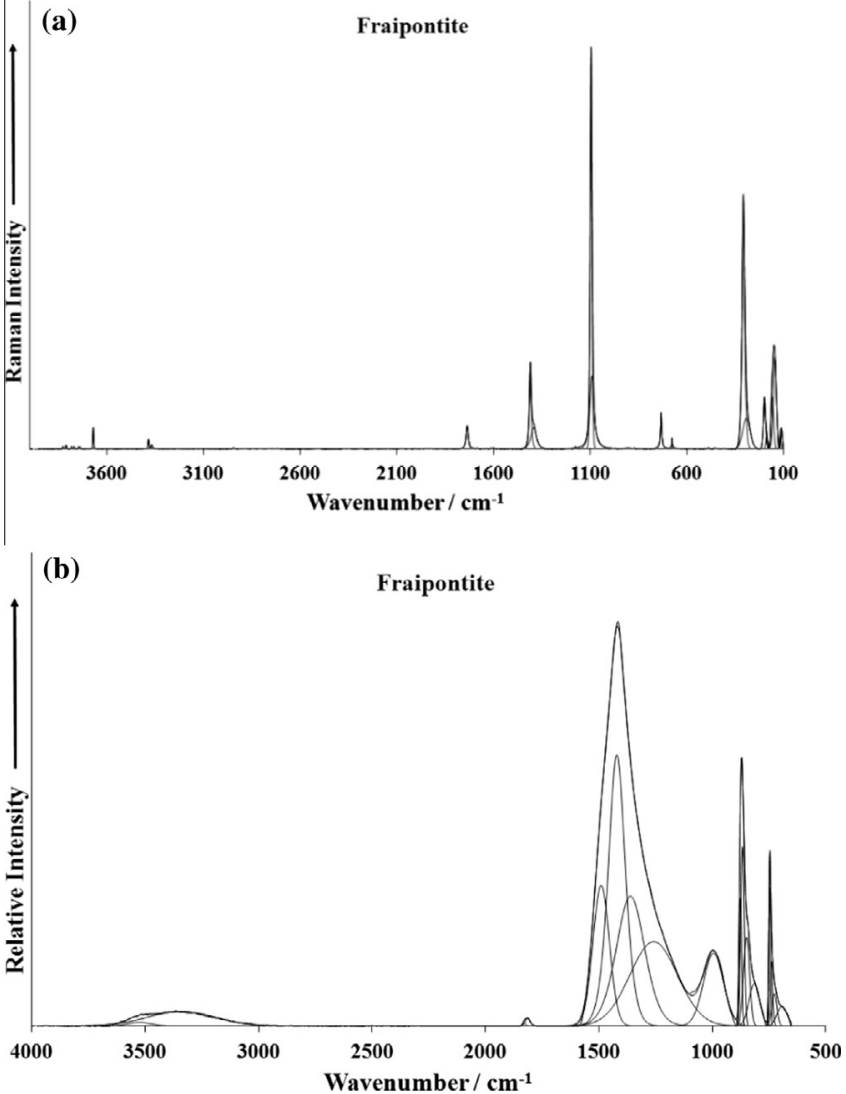

Fig. 3. (a) Raman spectrum of fraipontite over the $100-4000 \mathrm{~cm}^{-1}$ spectral range (b) infrared spectrum of fraipontite over the $500-4000 \mathrm{~cm}^{-1}$ spectral range. 


\section{Infrared spectroscopy}

Infrared spectra were obtained using a Nicolet Nexus 870 FTIR spectrometer with a smart endurance single bounce diamond ATR cell. Spectra over the $4000-525 \mathrm{~cm}^{-1}$ range were obtained by the co-addition of 128 scans with a resolution of $4 \mathrm{~cm}^{-1}$ and a mirror velocity of $0.6329 \mathrm{~cm} / \mathrm{s}$. Spectra were co-added to improve the signal to noise ratio.

Spectral manipulation such as baseline adjustment, smoothing and normalisation were performed using the Spectracalc software package GRAMS (Galactic Industries Corporation, NH, USA). Band component analysis was undertaken using the Jandel 'Peakfit' software package which enabled the type of fitting function to be selected and allows specific parameters to be fixed or varied accordingly. Band fitting was done using a Lorentz-Gauss crossproduct function with the minimum number of component bands used for the fitting process. The Lorentz-Gauss ratio was maintained at values greater than 0.7 and fitting was undertaken until reproducible results were obtained with squared correlations of $r^{2}$ greater than 0.995 .

\section{Results and discussion}

\section{Chemical characterisation}

The SEM/BSI image of the fraipontite crystal fragment studied in this work is shown in Fig. 1. The sample occurs in association with unidentified clay mineral. A perfect cleavage can be observed. Qualitative chemical analysis of fraipontite shows an aluminium silicate mineral with amounts of $\mathrm{Cu}$ and $\mathrm{Zn}$ (Fig. 2). It is likely there
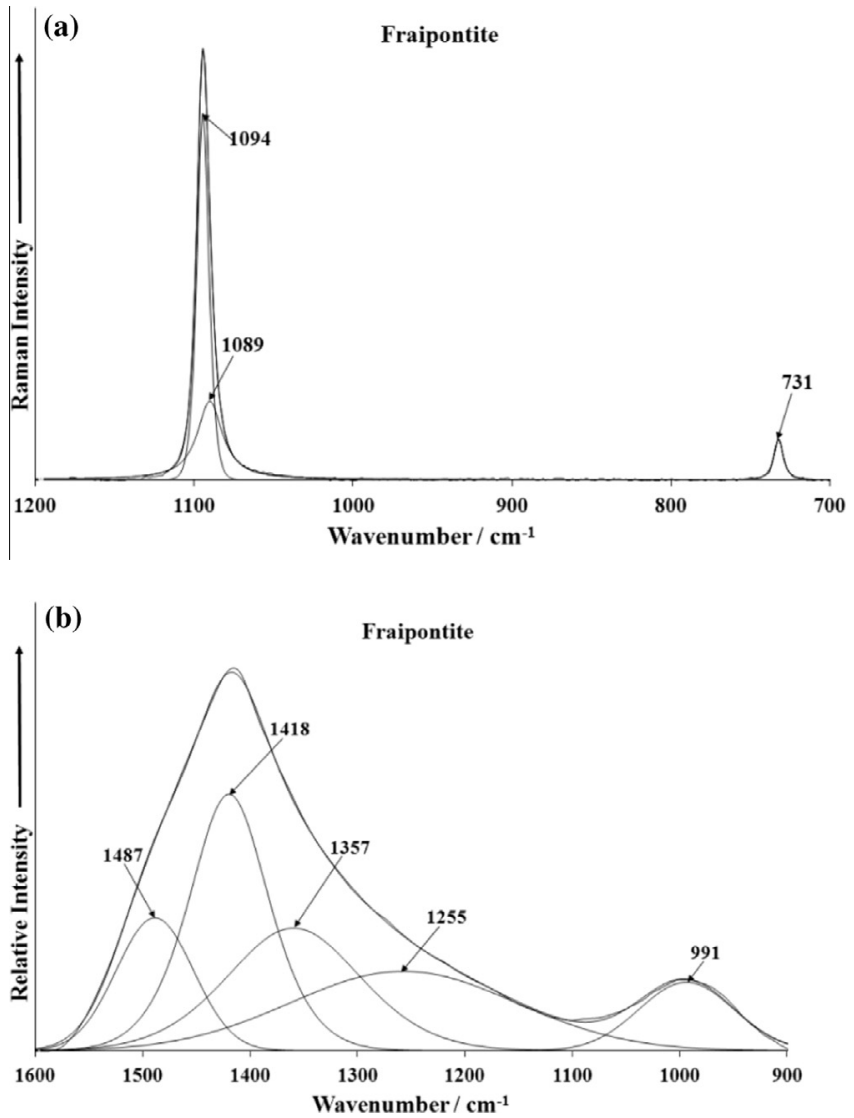

Fig. 4. (a) Raman spectrum of fraipontite over the $700-1200 \mathrm{~cm}^{-1}$ spectral range (b) infrared spectrum of fraipontite over the $900-1600 \mathrm{~cm}^{-1}$ spectral range. are low concentrations of rare earth elements in the chemical composition of fraipontite.

\section{Vibrational spectroscopy of fraipontite (IR and Raman)}

The Raman spectrum of fraipontite over the $4000-100 \mathrm{~cm}^{-1}$ spectral range is shown in Fig. 3a. This figure shows the position and relative intensity of the Raman bands of fraipontite. It is noted there are large parts of the spectrum where little or no intensity is observed, consequently the Raman spectrum is therefore subdivided into sections based upon the types of vibration being studied. Additionally it is noted that there is little intensity in the hydroxyl stretching region (2500-3800 $\mathrm{cm}^{-1}$ spectral range). The infrared spectrum of fraipontite over the $4000-500 \mathrm{~cm}^{-1}$ spectral range is displayed in Fig. $3 \mathrm{~b}$ which shows the position and relative intensities of the infrared bands. The infrared spectrum is also subdivided into sections based upon the type of vibration being analysed. Compared with the Raman, the infrared spectrum is quite broad and there is minimal intensity observed beyond $1500 \mathrm{~cm}^{-1}$.

The Raman spectrum of fraipontite over the $1200-700 \mathrm{~cm}^{-1}$ spectral range is shown in Fig. 4a. Two Raman bands are observed at 731 and $1094 \mathrm{~cm}^{-1}$ with a shoulder band at $1089 \mathrm{~cm}^{-1}$. These bands are assigned to the bending and stretching vibrations of the $\mathrm{SiO}$ units.

In contrast, the infrared spectrum of fraipontite over the 1600$900 \mathrm{~cm}^{-1}$ spectral range as shown in Fig. 4b displays broad bands with bands observed at 991, 1255, 1357, 1418 and $1487 \mathrm{~cm}^{-1}$. The infrared band at $991 \mathrm{~cm}^{-1}$ is assigned to the AlOH hydroxyl deformation mode. The other bands are attributed to $\mathrm{SiO}$ stretching vibrations. The strongest infrared band at around $1418 \mathrm{~cm}^{-1}$ is assigned to the presence of carbonate. The strong Raman band at $1094 \mathrm{~cm}^{-1}$ may also be assigned to the carbonate stretching vibration.
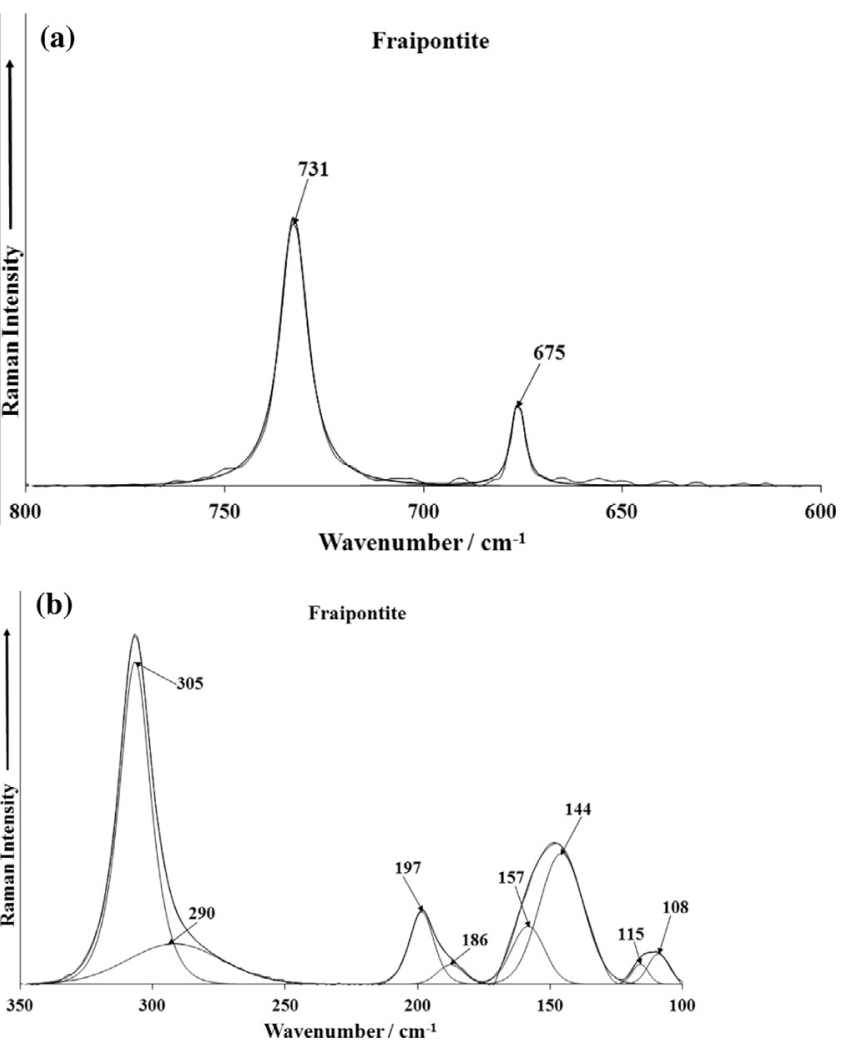

Fig. 5. (a) Raman spectrum of fraipontite over the $600-800 \mathrm{~cm}^{-1}$ spectral range (b) infrared spectrum of fraipontite over the $100-350 \mathrm{~cm}^{-1}$ spectral range. 


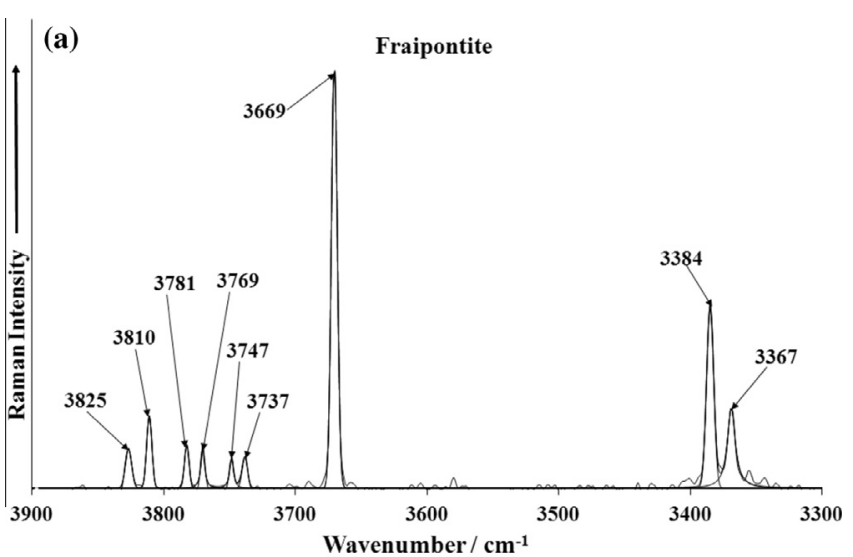

(b) Fraipontite

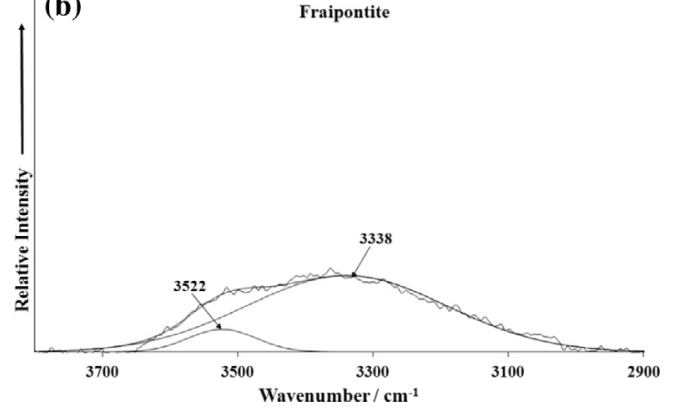

Fig. 6. (a) Raman spectrum of fraipontite over the $3300-3900 \mathrm{~cm}^{-1}$ spectral range (b) infrared spectrum of fraipontite over the $2900-3800 \mathrm{~cm}^{-1}$ spectral range.
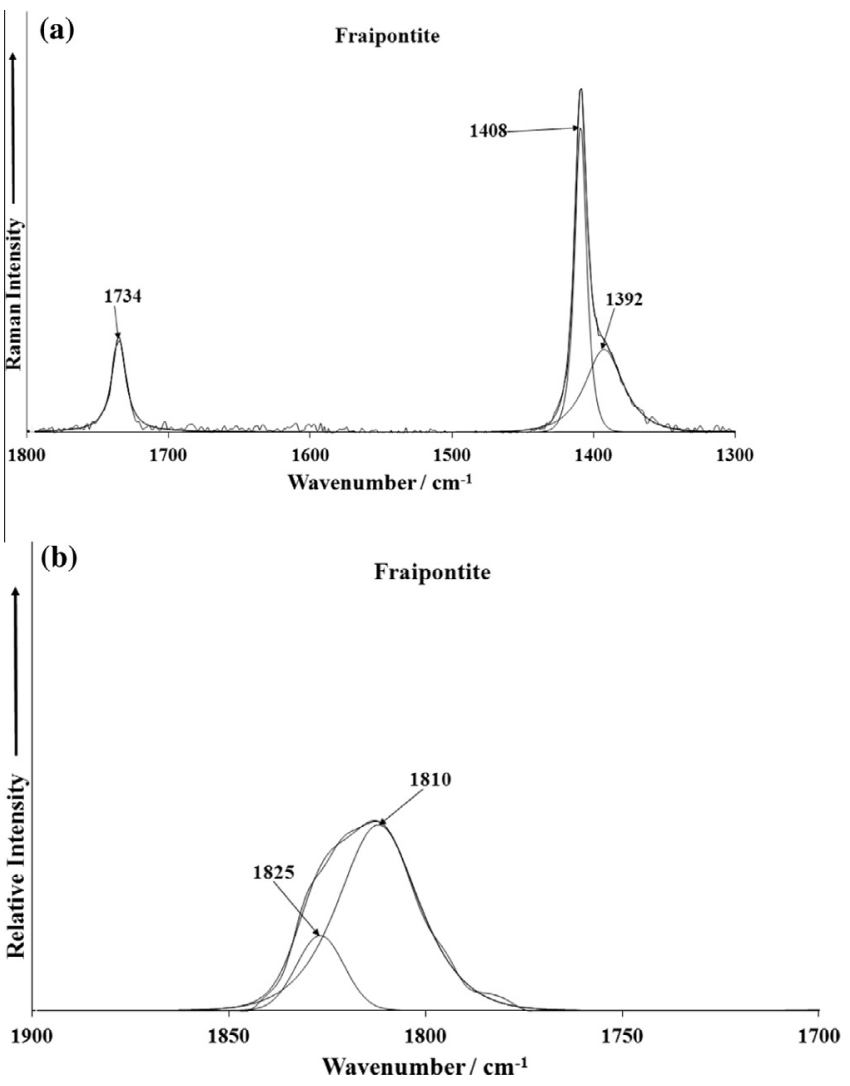

Fig. 7. (a) Raman spectrum of fraipontite over the $1300-1800 \mathrm{~cm}^{-1}$ spectral range (b) infrared spectrum of fraipontite over the $1700-1900 \mathrm{~cm}^{-1}$ spectral range.
The Raman spectrum of fraipontite over the $800-600 \mathrm{~cm}^{-1}$ spectral range is given in Fig. 5a. It should be noted that no bands were found in the $350-600 \mathrm{~cm}^{-1}$ spectral range. Two Raman bands are found at 675 and $731 \mathrm{~cm}^{-1}$. The Raman spectrum of fraipontite over the $350-100 \mathrm{~cm}^{-1}$ spectral range is given in Fig. $5 \mathrm{~b}$. An intense Raman band is found at $305 \mathrm{~cm}^{-1}$ was associated with the $\mathrm{OH}$ units. The Raman bands at 108, 115, 144, 157, 186 and $197 \mathrm{~cm}^{-1}$ could only be described as lattice vibrational modes.

The Raman spectrum of fraipontite over the $3900-3300 \mathrm{~cm}^{-1}$ spectral range is shown in Fig. 6a. The Raman bands at 3367 and $3384 \mathrm{~cm}^{-1}$ are assigned to water stretching vibrations. The sharp Raman band at $3669 \mathrm{~cm}^{-1}$ is assigned to the $\mathrm{AlOH}$ stretching vibration.

Some low intensity sharp bands are noted at 3737, 3747, 3769, $3781 \mathrm{~cm}^{-1}$ were attributed to $\mathrm{SiOH}$ stretching vibrations. In comparison, the infrared spectrum over the $2900-3800 \mathrm{~cm}^{-1}$ spectral range in Fig. 6b shows two broad bands are found at 3338 and $3522 \mathrm{~cm}^{-1}$ which are assigned to water $\mathrm{OH}$ stretching vibrations. There is an apparent disconnect between the Raman and infrared spectra. The Raman spectrum of fraipontite over the 1800$1300 \mathrm{~cm}^{-1}$ spectral range is reported in Fig. 7a. Raman bands are found at 1392 and $1408 \mathrm{~cm}^{-1}$ and are assigned to the antisymmetric stretching vibrations of the siloxane units. The attribution of the band at $1734 \mathrm{~cm}^{-1}$ is not known at this stage. The infrared spectrum of fraipontite over the $1900-1700 \mathrm{~cm}^{-1}$ spectral region is shown in Fig. 7b. Two bands are found at 1810 and $1825 \mathrm{~cm}^{-1}$.

\section{Conclusions}

In this work, we have studied the clay mineral fraipontite by a combination of SEM with EDX and vibrational spectroscopy. The qualitative chemical analysis of fraipontite is reported.

The kaolinite type mineral fraipontite has been studied by Raman spectroscopy. The Raman spectrum of fraipontite is characterised by intense bands at 675,731 and $1089 \mathrm{~cm}^{-1}$. Fraipontite is characterised by a series of bands in the hydroxyl stretching region. The Raman bands at 3367 and $3384 \mathrm{~cm}^{-1}$ are assigned to water stretching vibrations. The sharp Raman band at $3669 \mathrm{~cm}^{-1}$ is assigned to the $\mathrm{AlOH}$ stretching vibration. Two Raman bands at 731 and $1094 \mathrm{~cm}^{-1}$ are assigned to the bending and stretching vibrations of the SiO units. By using Raman spectroscopy, aspects of the molecular structure have been characterised.

\section{Acknowledgements}

The financial and infra-structure support of the Discipline of Nanotechnology and Molecular Science, Science and Engineering Faculty of the Queensland University of Technology, is gratefully acknowledged. The Australian Research Council (ARC) is thanked for funding the instrumentation. The authors would like to acknowledge the Center of Microscopy at the Universidade Federal de Minas Gerais (http://www.microscopia.ufmg.br) for providing the equipment and technical support for experiments involving electron microscopy. The authors are also grateful to CNPq Project 402852/2012-5.

\section{References}

[1] R.L. Frost, Clay Miner. 32 (1997) 65-77.

[2] R.L. Frost, A.M. Vassallo, Clays Clay Min. 44 (1996) 635-651.

[3] R.L. Frost, P.M. Fredericks, H.F. Shurvell, Can. J. Appl. Spectrosc. 41 (1996) 1014.

[4] R.L. Frost, Clays Clay Min. 43 (1995) 191-195.

[5] R.L. Frost, B.J. Reddy, M.J. Dickfos, J. Raman Spectrosc. 39 (2008) 909-913.

[6] J.T. Kloprogge, M. Hammond, R.L. Frost, Neues Jahrb. Mineral. Monatsh. (2000) 193-206. 
7] V. Maltsev, V. Korshunov, J. Cave Karst Stud. 60 (1998) 151.

[8] T.K. Berkeliev, L.A. Pautov, K.I. Ignatenko, Mineralogicheskii Zhurnal 14 (1992) 89-91.

[9] J.B. Perez, Y. Dusausoy, J. Babkine, M. Pagel, Am. Mineral. 75 (1990) 909.

[10] I.D. Parcalabescu, I. Nistor, Mine, Pet. Gaze, 35 (1984) 497.

[11] I.D. Parcalabescu, I. Nistor, Mine, Pet. Gaze 40 (1989) 42.

[12] P. Keller, W. Bartelke, Min. Rec. 13 (1982) 137.
13] A.M. Fransolet, P. Bourguignon, Bull. Soc. Fr. Min. Crist. 98 (1975) 235-244.

[14] S. Dimitriadis, Neues Jahrb. Mineral. Monatsh. (1977) 155-162.

[15] E.E. Foord, J.E. Taggart, N.M. Conklin, Min. Rec. 14 (1983) 131.

[16] N. Takahashi, M. Tanaka, T. Satoh, Nippon Kagaku Kaishi (1990) 370-375.

[17] N. Takahashi, M. Tanaka, T. Satoh, Nippon Kagaku Kaishi (1991) 962-967.

[18] N. Takahashi, M. Tanaka, T. Satoh, T. Endo, Bull. Chem. Soc. Jpn. 70 (1997) 609614 